\title{
Portal Hypertension Is the Main Driver of Liver Stiffness in Advanced Liver Cirrhosis
}

\author{
Mariia LUNOVA ${ }^{1}$, Sona FRANKOVA ${ }^{2}$, Halima GOTTFRIEDOVA ${ }^{2}$, Renata \\ SENKERIKOVA ${ }^{2}$, Magdalena NEROLDOVA ${ }^{1}$, Jozef KOVAC ${ }^{3}$, Eva KIESLICHOVA ${ }^{4}$, Vera \\ LANSKA $^{5}$, Eva STICOVA ${ }^{6}$, Julius SPICAK ${ }^{2}$, Milan JIRSA ${ }^{1,7}$, Jan SPERL ${ }^{1,8}$
}

${ }^{1}$ Laboratory of Experimental Hepatology, Institute for Clinical and Experimental Medicine, Prague, Czech Republic, ${ }^{2}$ Department of Hepatogastroenterology, Transplant Centre, Institute for Clinical and Experimental Medicine, Prague, Czech Republic, ${ }^{3}$ Department of Diagnostic and Interventional Radiology, Institute for Clinical and Experimental Medicine, Prague, Czech Republic,

${ }^{4}$ Anesthesiology, Resuscitation and Intensive Care Department, Institute for Clinical and Experimental Medicine, Prague, Czech Republic, ${ }^{5}$ Department of Biostatistics, Institute for Clinical and Experimental Medicine, Prague, Czech Republic, ${ }^{6}$ Department of Clinical and Transplant Pathology, Institute for Clinical and Experimental Medicine, Prague, Czech Republic, ${ }^{7}$ Institute of Medical Biochemistry and Laboratory Diagnostics, First Faculty of Medicine, Charles University, Prague, Czech Republic, ${ }^{8}$ Department of Internal Medicine, 1st Faculty of Medicine, Charles University and Military University Hospital, Prague, Czech Republic

Received December 1, 2020

Accepted April 12, 2021

Epub Ahead of Print June 2, 2021

\section{Summary}

Liver stiffness (LS) is a novel non-invasive parameter widely used in clinical hepatology. LS correlates with liver fibrosis stage in non-cirrhotic patients. In cirrhotic patients it also shows good correlation with Hepatic Venous Pressure Gradient (HVPG). Our aim was to assess the contribution of liver fibrosis and portal hypertension to LS in patients with advanced liver cirrhosis. Eighty-one liver transplant candidates with liver cirrhosis of various aetiologies underwent direct HVPG and LS measurement by 2D shear-wave elastography (Aixplorer Multiwave, Supersonic Imagine, France). Liver collagen content was assessed in the explanted liver as collagen proportionate area (CPA) and hydroxyproline content (HP). The studied cohort included predominantly patients with Child-Pugh class B and C (63/81, $77.8 \%)$, minority of patients were Child-Pugh A (18/81, $22.2 \%)$. LS showed the best correlation with HVPG $(r=0.719, p<0.001)$, correlation of LS with CPA $(r=0.441, p<0.001)$ and HP/Amino Acids $(r=0.414, p<0.001)$ was weaker. Both variables expressing liver collagen content showed good correlation with each other $(r=0.574, p<0.001)$. Multiple linear regression identified the strongest association between LS and HVPG $(p<0.0001)$ and weaker association of LS with CPA ( $p=0.01883)$. Stepwise modelling showed minimal increase in $\mathrm{r}^{2}$ after addition of CPA to HVPG (0.5073 vs. 0.5513). The derived formula expressing LS value formation is: $L S=2.48+(1.29 \times \mathrm{HVPG})+(0.26 \times \mathrm{CPA})$. We conclude that LS is determined predominantly by HVPG in patients with advanced liver cirrhosis whereas contribution of liver collagen content is relatively low.

\section{Key words}

Hepatic venous portal gradient - Elastography - Collagen • Hydroxyproline • Osteopontin

\section{Corresponding author}

Jan Sperl, Department of Hepatogastroenterology, Institute for Clinical and Experimental Medicine, Videnska 1958/9, 14021 Prague, Czech Republic. E-mail: jan.sperl@ikem.cz

\section{Introduction}

Chronic liver disease (CLD) result from the necro-inflammatory process damaging hepatocytes due to

PHYSIOLOGICAL RESEARCH • ISSN 1802-9973 (online) - an open access article under the CC BY-NC-ND 4.0 license (C) 2021 Institute of Physiology of the Czech Academy of Sciences, Prague, Czech Republic 
variety of origins and promoting progression of liver fibrosis to cirrhosis. Progression of liver fibrosis is associated with increase of liver stiffness (LS) caused by collagen deposition and distortion of liver architecture. Mechanical changes in liver parenchyma represent the major but not exclusive contributor to increased portal pressure since liver fibrosis is also accompanied by microvascular thrombosis, hepatic sinusoidal endothelial cell dysfunction and hepatic stellate cell activation resulting in increased vascular resistance (McConnell and Iwakiri 2018). Pathophysiology of portal hypertension (PH) development also includes adaptive changes such as splanchnic and systemic arterial vasodilatation, hyperdynamic circulation and formation of portosystemic collaterals. These adaptive changes can further increase the portal pressure (Berzigotti and Bosch 2014).

Hepatic vein pressure gradient (HVPG) represents the gold standard for evaluation of the presence and severity of $\mathrm{PH}$ in patients with liver cirrhosis in clinical hepatology (Bosch et al. 2009). HVPG is presumably the best validated tool for assessing the risk of severe complications in liver cirrhosis. HVPG higher than $10 \mathrm{~mm} \mathrm{Hg}$ is considered to be the cut-off value for clinically significant portal hypertension (CSPH) (Lebrec et al. 1980). Patients with CSPH are at risk of oesophageal varices, develop ascites and cirrhosis decompensation (Garcia-Tsao et al. 1985, Groszmann et al. 2005, Ripoll et al. 2007). HVPG higher than $12 \mathrm{~mm}$ $\mathrm{Hg}$ is associated with the risk of variceal bleeding, more than $16 \mathrm{~mm} \mathrm{Hg}$ with high mortality and HVPG higher than $20 \mathrm{~mm} \mathrm{Hg}$ predicts failure to control variceal bleeding (Abraldes et al. 2008, Silva-Junior et al. 2015). HVPG measurement by hepatic vein catheterization is an invasive procedure and therefore, there is a need for an accurate non-invasive method. LS measurement as a non-invasive predictor of portal hypertension has been extensively studied in the last decade. This approach failed to predict HVPG values higher than $10 \mathrm{~mm} \mathrm{Hg}$ in some studies (Procopet et al. 2015); contrarily, other authors proved good correlation between LS and HVPG also for high values of HVPG (Stefanescu et al. 2019). The factors influencing correlation between LS and HVPG should be elucidated in the future.

LS can be measured by elastography techniques which can non-invasively estimate liver fibrosis stage. Liver stiffness measurement (LSM) has been widely used in clinical hepatology to characterize the stage of chronic liver disease in the last two decades and almost completely replaced invasive liver biopsy. Apart from non-invasive assessment of liver fibrosis, LSM also offers the possibility of non-invasive evaluation of portal hypertension.

Quantitative elastography is based on the measurement of shear wave propagation through the region of interest in the liver parenchyma (Kennedy et al. 2018). Pulse-echo ultrasound acquisition is used to follow the propagation of the shear wave and to measure its velocity; the stiffer the tissue, the faster the shear wave propagates. Transient elastography (TE) is the most commonly used method in clinical hepatology (Sandrin et al. 2003). The shear wave is generated by a mechanical vibrator mounted on the axis of the probe. The method is fast and easy, but its use is limited by the presence of ascites. The layer of the liquid represents an obstacle when the mechanical vibration passes across the abdominal wall to the liver. TE showed an excellent diagnostic accuracy for diagnosis of liver cirrhosis in several meta-analyses, with AUROC values $>0.9$ (Friedrich-Rust et al. 2008, Li et al. 2016, Shaheen et al. 2007, Stebbing et al. 2010, Talwalkar et al. 2007, Tsochatzis et al. 2011). TE was better at ruling out rather than ruling in liver cirrhosis with negative predictive value $>90 \%$ in these meta-analyses. TE has also been shown to have an excellent performance in predicting CSPH, with two meta-analyses reporting AUROCs $\geq 0.9$ (Shi et al. 2013, You et al. 2017).

The ultrasound-based quantitative elastography systems have recently been implemented in the standard ultrasound systems and therefore they rapidly spread into clinical practice. The shear wave in the ultrasound-based systems is generated by an acoustic radiation force impulse (ARFI). ARFI techniques bring also the benefit of real-time imaging to direct the probe to the region of interest. ARFI is commonly available in two forms, point shear wave elastography (pSWE) and two-dimensional shear wave elastography (2D-SWE). Both ARFI techniques allow LSM also in patients with advanced liver cirrhosis who present with ascites. Furthermore, ARFI methods have demonstrated an excellent diagnostic performance in predicting CSPH and the presence of oesophageal varices (Cassinotto et al. 2015, Elkrief et al. 2015, Morishita et al. 2014, Thiele et al. 2020).

Magnetic resonance elastography (MRE) is considered a gold standard in quantitative elastography. This technique allows measurement of tissue stiffness during clinical MRI exams by encoding the propagation of shear waves into the MR phase signal. MRE has shown an excellent ability to detect liver fibrosis and 
cirrhosis (Singh et al. 2016, Singh et al. 2015). Furthermore, some blood biomarkers were identified as non-invasive markers of portal hypertension, but their diagnostic power seems to be less robust in comparison with LSM. On the other hand, the blood biomarkers may serve for the rapid diagnosis and further research in this field is needed (Bruha et al. 2016, Simbrunner et al. 2020).

The wide clinical experience showed that LS represents a unique parameter reflecting morphological (fibrosis) and circulatory changes associated with the progression of chronic liver disease. It is also obvious that the LS value consists of two components: static (fibrosis) and dynamic (portal hypertension). Liver fibrosis is generally accepted as the driving factor of liver dysfunction and portal hypertension; two human studies (Calvaruso et al. 2012, Nielsen et al. 2014) showed that in the cirrhotic liver, the correlation between liver collagen content (collagen proportionate area, CPA) and portal hypertension (HVPG) is weaker than the correlation between LS and HVPG in the aforementioned trials. Therefore, it seems likely that in cirrhotic patients, the main component constituting the LS value is portal hypertension, not collagen content. This hypothesis is supported by experiments on an artificial liver model or animal livers (Yang et al. 2017, Yarpuzlu et al. 2014, Yin et al. 2013).

The aim of our study was to assess the contribution of static and dynamic component to LS in patients with advanced liver cirrhosis. To achieve it, we conducted a study in liver transplant recipients. The study design allowed us to assess the collagen content in the explanted liver by two independent laboratory methods. LS and HVPG were assessed in the pre-transplant period. Furthermore, to refine the non-invasive estimation of HVPG, we searched for blood biomarkers specific for portal hypertension independent of liver fibrosis.

\section{Methods}

\section{Patients and study design}

This prospective study included 81 patients who underwent liver transplantation for liver cirrhosis of various aetiology between October 2016 and July 2018 at our Transplant centre and before liver transplantation had participated in the first part of the clinical study on noninvasive predictors of portal hypertension (Frankova et al. 2021). Briefly, 109 liver transplant candidates with liver cirrhosis of various aetiology were included in the clinical study and completed the first part of the study protocol which included liver stiffness measurement, direct HVPG measurement by liver vein catheterisation and blood sampling for biomarkers assessment. All the study participants were evaluated as liver transplant candidates according to the standard criteria (European Association for the Study of the Liver 2016) and 92 of them were enrolled into the waiting list. Eighty-three of them underwent liver transplantation and in 81 of them, the explanted liver was available for the assessment of the collagen content. The aim of the second part of the study was in detail described in the previous section. Patients with portal vein thrombosis, transjugular intrahepatic portosystemic shunt (TIPS), hepatorenal syndrome requiring vasoactive drugs administration or renal replacement therapy, severe bacterial infection or sepsis, pulmonary hypertension, variceal bleeding in the last 4 weeks, hepatocellular carcinoma outside of the Milan criteria (Mazzaferro et al. 1996) and ongoing alcohol abuse were not considered for the participation in the study and none of them was included. The study was approved by local Institutional Review Board (IRB of Institute for Clinical and Experimental Medicine and Thomayer's Hospital, Prague). All patients signed the informed consent with the participation in study and the explanted liver assessment.

\section{Blood sampling}

The study subjects were in a sitting position for at least $5 \mathrm{~min}$ (but not $>10 \mathrm{~min}$ ) before and during sampling. Venous blood was taken between 8 and 10 a.m. The Vacuette system (VACUETTE® TUBE $8 \mathrm{~mL} \mathrm{Z}$ Serum Separator Clot Activator cat. No. 455071, and VACUETTE® $9 \mathrm{ml} \mathrm{K3}$ EDTA Plasma Separator cat. No. 455036, both from Greiner Bio-One, Kremsmünster, Austria) was used together with 21-gauge needles (Greiner Bio-One). Separation of blood corpuscles was done within $60 \mathrm{~min}$ after sampling at $3000 \mathrm{~g}$ for $10 \mathrm{~min}$ (centrifuge Beckman Allegra, Beckman Coulter, Indianapolis, IN). Several serum and plasma aliquots of $500 \mu \mathrm{l}$ were prepared within $60 \mathrm{~min}$ after centrifugation. CryoKing tubes from Biologix Group Limited, Jinan, China, cat. No. 89-3101, were used to store serum and plasma aliquots at $-80{ }^{\circ} \mathrm{C}$ until analysis.

\section{Analytical methods}

Serum concentrations of hyaluronic acid (HA), Amino-Terminal Propeptide of Type III Procollagen (PIIINP), and Tissue Inhibitor of Matrix 
Metalloproteinase 1 (TIMP-1) were measured by the ADVIA Centaur ${ }^{\circledR}$ HA assay, lot 25,215,019, the ADVIA Centaur ${ }^{\circledR}$ PIIINP assay, lot 26,290,023, and the ADVIA Centaur ${ }^{\circledR}$ TIMP-1 assay, lot 28,900,016, respectively (Siemens Healthineers, Erlangen, Germany). ADVIA Centaur ELF calibrator was used for calibration of HA, PIIINP, and TIMP-1 assays and ADVIA Centaur ELF quality control materials (three levels) were used as assay controls. Repeatability (within-run CV) assessed as declared by the manufacturer was $<5.6,<4.2$, and $<3.3 \%$ for HA, PIIINP and TIMP-1, respectively. Intermediate precisions (between-run $\mathrm{CVs}$ ) were $<3.2$, $<5.1$, and $<5.5 \%$. The respective measurement ranges for HA, PIIINP, and TIMP-1 were 1.6-1000, 0.5-150, and $3.5-1300 \mathrm{ng} / \mathrm{ml}$. Traceability was not provided by the manufacturer. Limits of detection of HA, PIIINP, and TIMP-1 were $1.6,0.5$ and $3.5 \mathrm{ng} / \mathrm{ml}$. All measurements were performed in one run during one day by the same laboratory technician using a Centaur CP immunochemistry analyzer (Siemens Healthineers). The Enhanced Liver Fibrosis (ELF) was calculated according to the Centaur CP formula: $0.846 \times \ln (\mathrm{HA})+0.735 \times \ln$ $($ PIIINP) $+0.391 \times \ln ($ TIMP-1) +2.494 .

Interleukin-6 (IL-6), Vascular Cell Adhesion Molecule 1 (VCAM-1), Interleukin-1 Receptor Antagonist (IL-1ra/IL-1F3), Osteopontin and Tumour Necrosis Factor alpha $(\mathrm{TNF} \alpha)$ were assessed in plasma samples obtained from the study subjects according to the manufacturer's instructions using the assays No. HS600B, DVC00, DRA00B, DOST00, and HSTA00E, respectively, all purchased from R\&D Systems, Minneapolis, MN. The absorbance was measured on a Synergy 2 Multi-Detection Microplate Reader (BioTek Instruments, Winooski, VT).

\section{HVPG measurement}

The radiologist performing HVPG measurements was blinded to elastography results. HVPG was determined by catheterization of the hepatic veins. An open-end zero-side holes 5F multipurpose angiographic catheter (Cordis, Santa Clara, CA) was inserted through a 6F sheath (Super Arrow-Flex Percutaneous Sheath Introducer Set, Arrow International brand of Teleflex, Wayne, PA) using the transjugular route. Iodinated radiological contrast medium was injected into the right or middle hepatic vein to confirm the position of the catheter in a wedged position by flouroscopy. The pressure was measured five times to demonstrate reproducibility and the mean value was used for further calculations. HVPG was calculated as the difference between wedged and free hepatic venous pressures.

\section{Liver stiffness (LS) measurement}

After an overnight fasting, 2D-SWE was performed using the Aixplorer ${ }^{\circledR}$ ultrasound system (Supersonic Imagine S.A., Aix-en-Provence, France) with an abdominal 3.5 MHz curved array probe (SC6-1). The examinations were performed \pm 7 days HVPG measurement. The operator was not aware of HVPG results when performing 2D-SWE. All patients were in the supine position and the right arm maximally abducted and LS measurements were performed on the right lobe of the liver through the intercostal spaces. RT-SWE were acquired using a $3.5 \times 2.5 \mathrm{~cm}$ box, more than $2 \mathrm{~cm}$ under the liver capsule and avoiding large vessels. During the examination the patient was requested to hold breath as needed. After obtaining a stable and homogenous elastographic image inside the box, a region of interest (ROI) was selected using the Q-box tool and placed in the most homogeneous area and the median values of LS within the ROI was displayed and registered. The diameter of the Q-box was set $>15 \mathrm{~mm}$. Three elastographic images from different liver areas were obtained in all patients and the mean value was used for further calculations.

\section{Non-invasive predictors of portal hypertension}

The MELD score (Model for End-Stage Liver Disease) is a composite predictor of survival in patients with cirrhosis calculated from total serum bilirubin, serum creatinine and the international normalized ratio (INR). MELD score was originally invented to predict short-term survival in cirrhotic patients (Kamath et al. 2007). Later studies showed that MELD score correlates with MR elastography results, presence of varices and mortality in patients with variceal bleeding (Conejo et al. 2018, Hoffman et al. 2020) and is currently used to prioritize liver transplantation (Kamath et al. 2007, Wiesner et al. 2003, Wiesner et al. 2001).

LSPS (Liver Spleen Platelets Score) is also a composite predictor combining LS, platelets count and spleen diameter (Berzigotti 2013). LSPS was calculated as described previously: [LS (in kiloPascals) $\mathrm{x}$ spleen diameter (in centimetres)]/platelet count ratio ( $\left.\times 10^{9} / 1\right)$. LSPS was superior to LS alone for identification of patients with CSPH in a study by Berzigotti et al. (2013).

VCAM-1 is an inflammatory biomarker 
correlating most significantly with HVPG in the study (Buck et al. 2014). Osteopontin, acting as a key component of bone matrix and multifunctional cytokine, also correlated well with HVPG in humans (Bruha et al. 2016).

The ELF score was shown to correlate with the stage of liver fibrosis in liver diseases of various aetiologies (Miele et al. 2017, Parkes et al. 2011, Parkes et al. 2010). Therefore, we decided to evaluate ELF score and its individual components as potential marker(s) of portal hypertension.

\section{Collagen proportionate area (CPA) evaluation}

Four tissue blocks measuring $15 \times 15$ × $2 \mathrm{~mm}$ were prepared from each liver explant and routinely processed for histological evaluation. Two $4 \mu \mathrm{m}$-thick sections histochemically stained by Picro-Sirius Red (PSR) technique to visualize collagen were prepared from each paraffin block. Analysis of collagen proportionate area (CPA) was performed by histomorphometry using a 3DHistech Pannoramic Desk II DW digital slide scanner (3DHistech Kft., Budapest, Hungary) and Nikon NIS-Elements AR 3.2 morphometric program (Nikon, Tokyo, Japan). Whole sections were scanned with 60x objective in transmitted light. Total tissue area was determined by thresholding in intensity mode. Subsequently, PSR-stained areas occupied by collagen were separated using Red, Green, and Blue (RGB) thresholding. The CPA percentage was expressed as the proportion of the collagen areas highlighted by PSR to the total tissue section surface.

\section{Hydroxyproline to total Amino Acids ratio (HP/AA)}

Colorimetric hydroxyproline assay detecting 3-hydroxy, 4-hydroxy and 5-hydroxyproline species was performed as described (Lunova 2014). Briefly, approximately $1 \mathrm{~g}$ of liver tissue sample was deparaffinized and mechanically homogenized to powder. Fifty $\mathrm{mg}$ of liver powder was then hydrolyzed in $6 \mathrm{~N} \mathrm{HCL}$ at $110^{\circ} \mathrm{C}$ for 18 hours, filtered to remove the debris and $50 \mu \mathrm{l}$ of each sample was evaporated by speed vacuum centrifugation. The pellets or standards (trans-4hydroxy-L-proline, Sigma) were dissolved in $50 \mu \mathrm{l}$ of distilled water, mixed with $56 \mathrm{mM}$ chloramine - T trihydrate (Sigma, Saint Louis, MO) in acetate - citrate buffer $(\mathrm{pH}=6.5)$ and incubated for $25 \mathrm{~min}$ at room temperature. After that, Ehrlich solution (Sigma) was added to form the desired chromophore at $65{ }^{\circ} \mathrm{C}$ during $30 \mathrm{~min}$ incubation. Absorbance was measured at $570 \mathrm{~nm}$ by using the Synergy ${ }^{\mathrm{TM}} 2$ Multi-Detection Microplate Reader (BioTek Instruments, Winooski, VT).

To determine total amino acids in liver samples, Ninhydrin reaction was used in pursuance of the manufacturer's recommendations. $50 \mu \mathrm{l}$ aliquots of the filtered hydrolyzed liver samples (see hydroxyproline assay) were dried by vacuum centrifugation and then dissolved in distilled water. The samples or 40-1400 nM of amino acids (AA-S-18, Sigma) were mixed with Ninhydrin reagent solution (Sigma) in ratio 2:1, respectively, and incubated $10 \mathrm{~min}$ at $100^{\circ} \mathrm{C}$. Then the samples and standards were brought to room temperature and further mixed with $95 \%$ ethanol (Sigma) in ratio 3:5, respectively. After that, absorbance was measured at 570 nm using the Synergy ${ }^{\mathrm{TM}} 2$ Multi-Detection Microplate Reader (BioTek).

\section{Statistical analysis}

Statistical analyses were performed using the SigmaPlot 11.0 (Systat Software Inc., San Jose, CA) or JMP 11.0.0 software (2013, SAS Institute Inc.). Clinical characteristics were analysed in a descriptive way and reported as mean \pm standard deviation, or median and range, as appropriate. Where assumptions of normal distributions were not met, Shapiro-Wilk test was used to evaluate the normal distribution of data. Spearman's test was used for correlations among continuous variables. Medians were compared using t-test or Mann-Whitney test, as appropriate. Similarly, multiple comparisons were done by one way ANOVA or Kruskal-Wallis test. Statistical significance was defined as $\mathrm{p}$ value $<0.05$ for all calculations.

\section{Results}

\section{Patient characteristics}

Eighty-one consecutive patients were prospectively enrolled in the study. All patients had advanced liver cirrhosis of various aetiologies and were potential candidates for liver transplantation. All enrolled patients underwent blood draw for biomarkers, LS and HVPG measurement, both examinations were included in the pre-transplant screening protocol. All 81 patients underwent thereafter liver transplantation and CPA and HP/AA were assessed in the explanted liver. The median period between study recruitment and liver transplantation was 105 days (range 10-769 days). All patients received the graft from the heart-beating donors after brain death, age of the donors ranged from 21 to 
81 years. None of the organ donors was from a vulnerable population and none of the donors was registered in the National Registry of people opposed to the post-mortem withdrawal of tissues and organs. The aetiology of liver cirrhosis is shown in the Table 1. The patients were divided into two subgroups according to the Child-Pugh classification of liver dysfunction: patients classified as Child-Pugh A $(18 / 81,22.2 \%)$ and patients with ChildPugh class $\mathrm{B}$ and $\mathrm{C}(63 / 81,77.8 \%)$. The measured HVPG values were from 6 to $31 \mathrm{~mm} \mathrm{Hg}$. Only 7 (8.6\%) patients had HVPG lower than $10 \mathrm{~mm} \mathrm{Hg}$; the overwhelming majority $74(91.4 \%)$ had CSPH, i.e. HVPG $\geq 10 \mathrm{~mm} \mathrm{Hg}$. There were 34 of 81 patients treated with carvedilol (non-selective $\beta$-blocker), all 34 patients had a low daily dose of $6.25 \mathrm{mg}$ (3.125 mg twice daily). Only 3 patients were given atorvastatin at a daily dose of $20 \mathrm{mg}$, none of the 3 patients on atorvastatin received carvedilol concomitantly. The detailed characteristics of the patients are presented in Tables 1 and 2 .

Table 1: Baseline clinical and laboratory characteristics of the whole cohort and patient subgroups

\begin{tabular}{|c|c|c|c|c|}
\hline $\begin{array}{l}\text { Variable } \\
\text { [median, range] }\end{array}$ & $\begin{array}{c}\text { All patients } \\
\mathrm{N}=\mathbf{8 1}(\mathbf{1 0 0} \%)\end{array}$ & $\begin{array}{c}\text { Child-Pugh A } \\
\text { patients } \\
\text { N = } 18(22.2 \%)\end{array}$ & $\begin{array}{c}\text { Child-Pugh } B \text { and } \\
\text { C patients } \\
\text { N }=63(77.8 \%)\end{array}$ & $P$ (test) \\
\hline Age [years] & $61(21-74)$ & $68(53-74)$ & $56(21-73)$ & $<0.001(\mathrm{MW})$ \\
\hline Gender [Male] & $55(68.0 \%)$ & $13(72.2 \%)$ & $42(66.7 \%)$ & N.S. (MW) \\
\hline$B M I\left[\mathrm{~kg} / \mathrm{m}^{2}\right]$ & $27.3(18.4-38.5)$ & $28.7(21.6-35.4)$ & $25.7(18.4-38.5)$ & $0.011(\mathrm{t})$ \\
\hline $\begin{array}{l}\text { Child-Pugh score [points] } \\
\text { Aetiology of liver cirrhosis }\end{array}$ & $8(5-13)$ & $6(5-6)$ & $8(7-13)$ & $<0.001(\mathrm{MW})$ \\
\hline Alcohol & $28(34.6 \%)$ & $7(38.9 \%)$ & $21(33.4 \%)$ & \\
\hline$N A S H$ & $9(11.1 \%)$ & $4(22.2 \%)$ & $5(7.9 \%)$ & \\
\hline Cryptogenic & $7(8.6 \%)$ & $0(0.0 \%)$ & $7(11.1 \%)$ & \\
\hline Viral $(H B V / H C V)$ & $13(16.0 \%)$ & $7(38.9 \%)$ & $6(9.5 \%)$ & $<0.001(\mathrm{~F})$ \\
\hline Cholestatic and & $22(27.2 \%)$ & $0(0 \%)$ & $22(34.9 \%)$ & \\
\hline autoimmune & $2(2.5 \%)$ & $0(0 \%)$ & $2(3.2 \%)$ & \\
\hline \multicolumn{5}{|l|}{ Metabolic } \\
\hline MELD score [points] & $15(6-37)$ & $9(6-21)$ & $15(7-37)$ & $<0.001(\mathrm{MW})$ \\
\hline Overt hepatic & 10 & 0 & 10 & $0.026(\mathrm{~F})$ \\
\hline encephalopathy & $(12.3 \%)$ & $(0 \%)$ & $(15.9 \%)$ & \\
\hline Spleen diameter $[\mathrm{cm}]$ & $16(9-25)^{*}$ & $15(9-18)$ & $16(9-25)^{*}$ & $0.005(\mathrm{MW})$ \\
\hline Oesophageal varices & $19 / 25 / 37$ & $5 / 6 / 7$ & $14 / 19 / 30$ & N.S. (F) \\
\hline (none/small/large) & $(23.4 / 30.9 / 45.7 \%)$ & $(27.8 / 33.3 / 38.9 \%)$ & $(22.2 / 30.1 / 47.7 \%)$ & \\
\hline $\begin{array}{l}\text { History of variceal } \\
\text { bleeding }\end{array}$ & $17(21.0 \%)$ & $3(16.7 \%)$ & $14(22.2 \%)$ & N.S. (F) \\
\hline Ascites (none/small/large) & $\begin{array}{c}40 / 16 / 25 \\
(49.4 / 19.7 / 30.9 \%)\end{array}$ & $\begin{array}{c}16 / 2 / 0 \\
(98.9 / 11.1 / 0 \%)\end{array}$ & $\begin{array}{c}24 / 14 / 25 \\
(38.1 / 22.2 / 39.7 \%)\end{array}$ & $<0.001(\mathrm{~F})$ \\
\hline Platelet count $\left[\times 10^{9} / l\right]$ & $93(40-344)$ & $94(48-286)$ & $93(40-344)$ & N.S. (t) \\
\hline Bilirubin [ $\mu \mathrm{mol} / \mathrm{l}]$ & $34(5-257)$ & $19(5-31)$ & $43(8-257)$ & $<0.001(\mathrm{t})$ \\
\hline Albumin $[\mathrm{g} / \mathrm{ll}$ & $30(17-45)$ & $37(29-45)$ & $28(17-40)$ & $<0.001(\mathrm{t})$ \\
\hline
\end{tabular}

${ }^{*}$ One value missing. MW - Mann-Whitney rank sum test, $\mathrm{F}-$ Fisher exact test, $\mathrm{t}$ - $\mathrm{t}$-test

The variables were compared between the subgroups of patients according to the aetiology of liver cirrhosis. There were no significant differences found between the subgroups in LS, CPA, HP/AA, ELF score, osteopontin (Fig. 1A), and MELD and Child-Pugh scores
(Fig. 1B). Only HVPG was significantly higher in the subgroup of patients with alcoholic liver disease than in the subgroup of patients with viral aetiology of liver cirrhosis (Fig. 1A). 


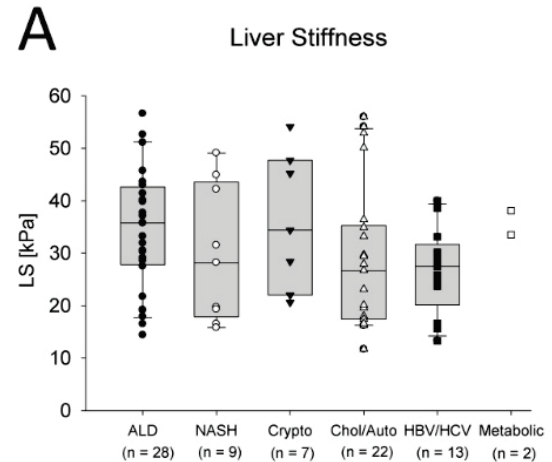

ELF Score

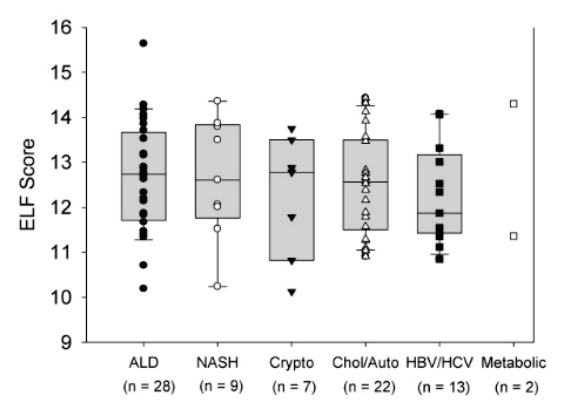

B

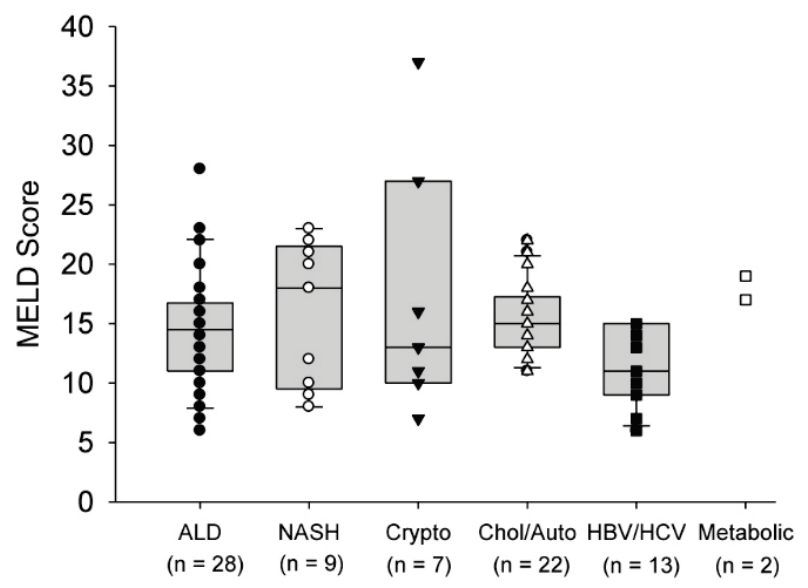

HVPG

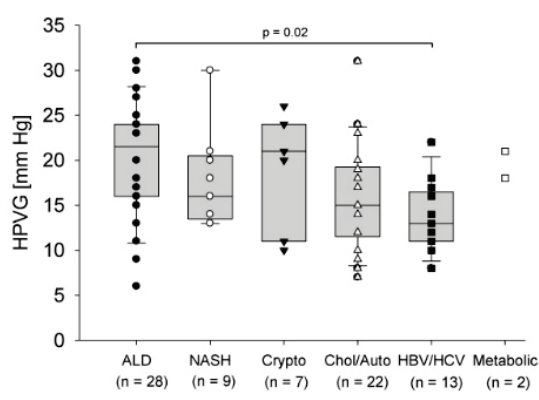

Hydroxyprolin to Total Amino Acids Ratio

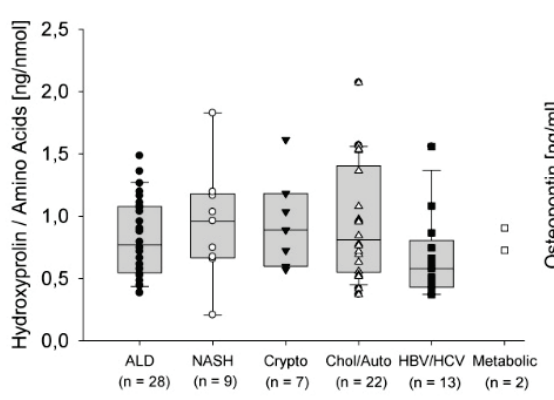

Collagen Proportionate Area

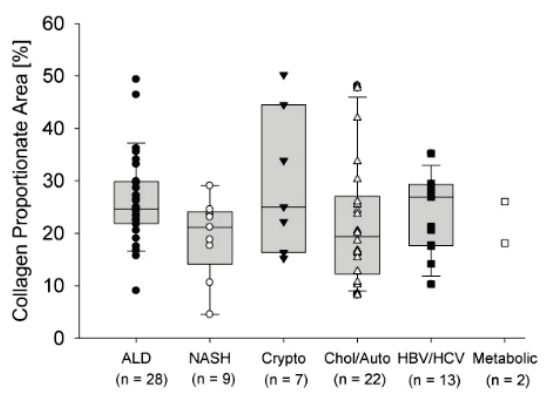

Osteopontin

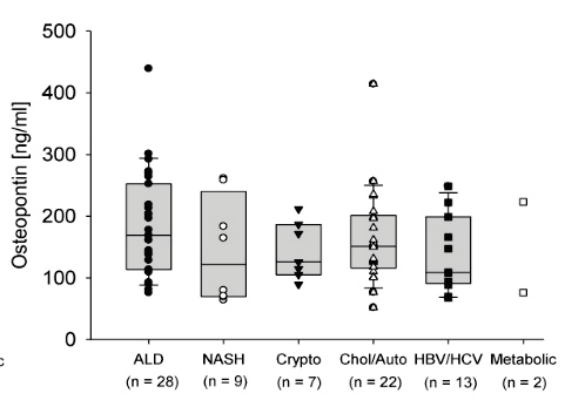

Child Pugh Score

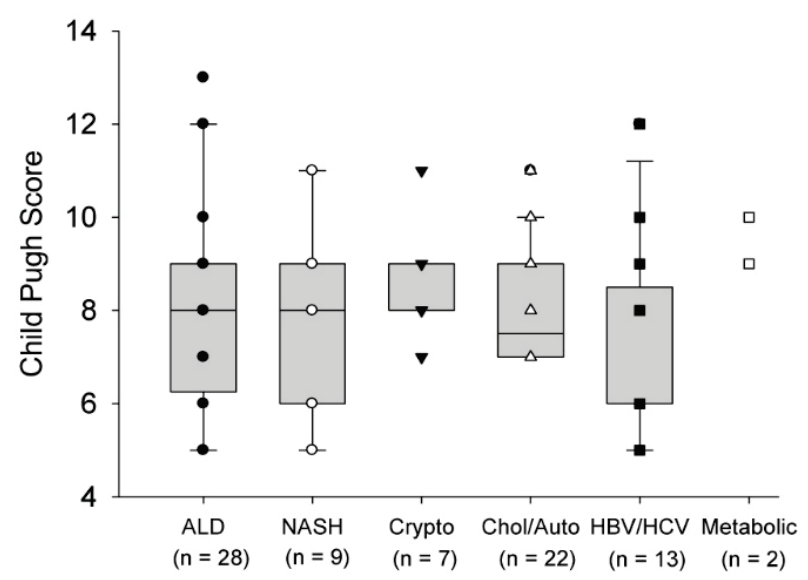

Fig. 1. Comparison of $L S, H V P G$, collagen content (CPA and HP/AA), ELF and osteopontin (A) and liver function scores (B) between subgroups of patients according to the aetiology of the liver cirrhosis. The data of two patients with metabolic liver disease were displayed but not included in the statistical analysis.

Correlations of HVPG and collagen content with their non-invasive markers

As the next step, correlations between LS, HVPG, liver collagen content (expressed as CPA or HP/AA) and non-invasive blood biomarkers of liver fibrosis and portal hypertension were calculated. The obtained Spearman's non-parametric correlation coefficients are presented in Table 3. The strongest correlation with LS was achieved for HVPG, the correlations with $\mathrm{CPA}, \mathrm{HP} / \mathrm{AA}$ and osteopontin were weaker. The regression lines for these correlations are displayed in Figure 2. It is evident that the lines have a different slope and HVPG increases well with LS whereas CPA or HP/AA increases more slowly. The correlation of LS with CPA or HP/AA was almost identical since both variables reflect liver collagen content. Accordingly, CPA and HP/AA showed a good correlation between each other $(\mathrm{r}=0.574$; $\mathrm{p}<0.001)$. Interestingly, HVPG, LS, LSPS, all associated with portal hypertension rather than collagen content showed better correlation with CPA than with HP/AA. On the other hand, ELF score and its components showed a better 
Table 2. Liver stiffness, HVPG, blood predictors of HVPG and fibrosis, and liver collagen content. All comparisons between Child-Pugh A patients and Child-Pugh $B$ and $C$ patients were done by Mann Whitney Rank Sum test.

\begin{tabular}{lcccc}
\hline $\begin{array}{l}\text { Variable } \\
\text { [median, range] }\end{array}$ & $\begin{array}{c}\text { All patients } \\
\mathbf{N}=\mathbf{8 1} \mathbf{( 1 0 0} \mathbf{\%})\end{array}$ & $\begin{array}{c}\text { Child-Pugh A } \\
\text { patients } \\
\mathbf{N}=\mathbf{1 8}(\mathbf{2 2 . 2} \mathbf{\%})\end{array}$ & $\begin{array}{c}\text { Child-Pugh B and C } \\
\text { patients } \\
\mathbf{N}=\mathbf{6 3}(\mathbf{7 7 . 8} \mathbf{\%})\end{array}$ & P \\
\hline Liver stiffness [kPa] & $30.0(11.7-56.6)$ & $19.5(13.3-39.8)$ & $33.2(11.7-56.6)$ & $<0.001$ \\
HVPG [mm Hg] & $17(6-31)$ & $14(8-20)$ & $18(6-31)$ & $<0.001$ \\
LSPS [points] & $4.9(0.6-27.9)^{*}$ & $3.2(0.8-8.8)$ & $5.5(0.6-27.9)^{*}$ & 0.006 \\
ELF score & $12.6(10.1-15.6)$ & $11.8(10.2-13.0)$ & $12.7(10.1-15.6)$ & $<0.001$ \\
Osteopontin [ng/ml] & $150(52-439)^{* *}$ & $109(64-169)$ & $177(52-439)^{* *}$ & $<0.001$ \\
VCAM-1 [ng/ml] & $2906(579-10268)^{*}$ & $1833(579-4509)$ & $3378(1134-10268)^{*}$ & $<0.001$ \\
TIMP-1 [ng/ml] & $475(219-1834)$ & $316(219-514)$ & $528(226-1834)$ & $<0.001$ \\
PIIINP [ng/ml] & $21.8(6.3-71.6)$ & $18.0(11.3-33.6)$ & $25.5(6.3-71.6)$ & 0.01 \\
Hyaluronic acid [ng/ml] & $564(43-6872)$ & $350(43-1269)$ & $700(57-6872)$ & 0.013 \\
Hydroxyproline/amino & $0.77(0.21-2.07)$ & $0.53(0.21-1.11)$ & $0.89(0.37-2.07)$ & $<0.001$ \\
acids [ng/nmol] & & & & \\
Collagen area [\%] & $23.4(4.5-50.2)$ & $18.4(4.5-36.2)$ & $24.4(8.2-50.2)$ & 0.028 \\
\hline
\end{tabular}

*one sample missing, ${ }^{* *}$ two samples missing.

Table 3. Correlation between HVPG, LS, collagen content (CPA or HP/AA) and their non-invasive markers.

\begin{tabular}{|c|c|c|c|c|c|c|c|c|}
\hline \multirow[t]{2}{*}{ Variable } & \multicolumn{2}{|c|}{ HVPG } & \multicolumn{2}{|c|}{ Liver stiffness } & \multicolumn{2}{|c|}{ CPA } & \multicolumn{2}{|c|}{$\begin{array}{c}\text { Hydroxyproline/Amino } \\
\text { Acids }\end{array}$} \\
\hline & $\begin{array}{c}\text { Spearman's } \\
\mathbf{r} \\
\end{array}$ & $\mathbf{p}$ & $\begin{array}{c}\text { Spearman's } \\
\mathbf{r}\end{array}$ & $\mathbf{p}$ & $\begin{array}{c}\text { Spearman's } \\
\mathbf{r} \\
\end{array}$ & $\mathbf{p}$ & $\begin{array}{c}\text { Spearman's } \\
\mathbf{r}\end{array}$ & $\mathbf{p}$ \\
\hline \multicolumn{9}{|l|}{ Liver stiffness } \\
\hline$[\mathrm{kPa}]$ & 0.719 & $<0.001$ & N.A. & N.A. & 0.441 & $<0.001$ & 0.414 & $<0.001$ \\
\hline$L S P S$ [points] ${ }^{*}$ & 0.419 & $<0.001$ & 0.481 & $<0.001$ & 0.303 & 0.006 & 0.126 & N.S. \\
\hline \multicolumn{9}{|l|}{ MELD score } \\
\hline [points] & 0.216 & N.S. & 0.413 & $<0.001$ & 0.073 & N.S. & 0.234 & 0.034 \\
\hline \multicolumn{9}{|l|}{ Spleen diameter } \\
\hline$[\mathrm{cm}]$ & 0.113 & N.S. & 0.059 & N.S. & 0.005 & N.S. & 0.047 & N.S. \\
\hline Platelets $\left[\times 10^{9} / l\right]$ & 0.008 & N.S. & 0.140 & N.S. & -0.181 & N.S. & 0.042 & N.S. \\
\hline \multicolumn{9}{|l|}{ Osteopontin } \\
\hline$[\mathrm{ng} / \mathrm{ml}]^{* *}$ & 0.404 & $<0.001$ & 0.390 & $<0.001$ & 0.071 & N.S. & 0.188 & N.S. \\
\hline$V C A M-1[\mathrm{ng} / \mathrm{ml}]^{*}$ & 0.352 & 0.002 & 0.443 & $<0.001$ & 0.317 & 0.004 & 0.236 & 0.035 \\
\hline TIMP-1 [ng/ml] & 0.346 & 0.002 & 0.471 & $<0.001$ & 0.235 & 0.004 & 0.340 & 0.002 \\
\hline \multicolumn{9}{|l|}{ ELF score } \\
\hline [points] & 0.271 & 0.015 & 0.337 & 0.002 & 0.347 & 0.002 & 0.470 & $<0.001$ \\
\hline$H A[n g / m l]$ & 0.203 & N.S. & 0.305 & 0.006 & 0.321 & 0.004 & 0.449 & $<0.001$ \\
\hline PIIINP $[\mathrm{ng} / \mathrm{ml}]$ & 0.183 & N.S. & 0.203 & N.S. & 0.252 & 0.023 & 0.407 & $<0.001$ \\
\hline$H P / A A[n g / n m o l]$ & 0.327 & 0.003 & 0.414 & $<0.001$ & 0.574 & $<0.001$ & N.A. & N.A. \\
\hline$C P A[\%]$ & 0.324 & 0.003 & 0.441 & $<0.001$ & N.A. & N.A. & 0.574 & $<0.001$ \\
\hline
\end{tabular}

${ }^{*}$ one sample missing, ${ }^{* *}$ two samples missing, N.A. not applicable, N.S. not significant

correlation with HP/AA than with CPA. Osteopontin showed a good correlation with LS and HVPG but it did not correlate well with CPA and HP/AA. Therefore, osteopontin represents the most specific blood biomarker 
of portal hypertension from the tested set. Similarly, LSPS correlated well with LS and HVPG better than with CPA. Administration of the low dose of carvedilol did not improve the correlation between LS and HVPG $(\mathrm{r}=0.6050$, CI $95 \% 0.3262-0.7870, \mathrm{p}=0.0002$ for
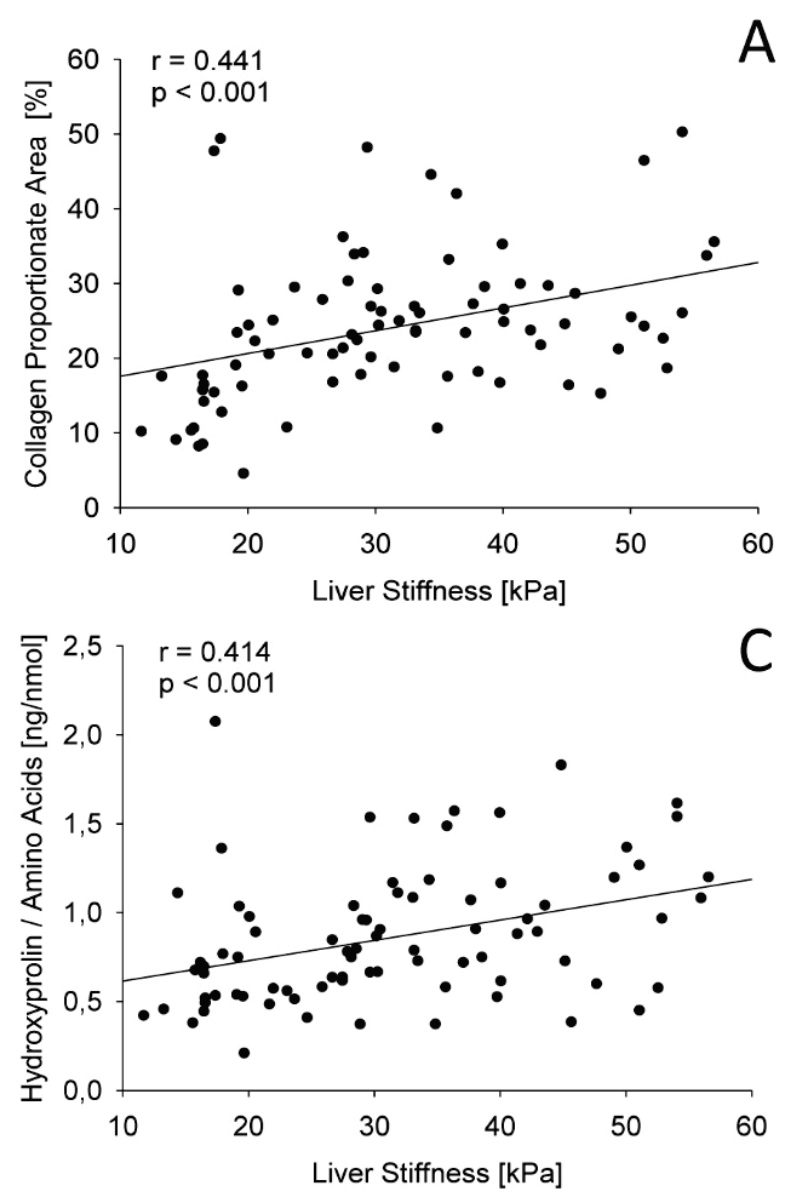

Fig. 2. Regression lines representing relation between LS and CPA (A), HVPG (B), HP/ AA (C) and osteopontin (D).

Modelling of a composite predictive factor

LS, considered as a dependent variable, and HVPG, CPA, HP/AA together with other studied noninvasive predictors considered as independent variables, were analysed by the multiple linear regression (Table 4). The strongest association was found between LS and HVPG ( $p<0.0001)$. A weaker association was found between LS and CPA $(p=0.0188)$ and even weaker association was found between LS and osteopontin $(\mathrm{p}=0.0241)$. The stepwise modelling showed only a minimal increase in $r^{2}$ after addition of CPA to HVPG (0.5073 vs. 0.5513$)$ and further addition of osteopontin increased $\mathrm{r}^{2}$ only to 0.5795 . The stepwise modelling showed that major contribution to the LS value formation had HVPG and the contribution of CPA and osteopontin were minimal. The derived formula expressing LS value subgroup on carvedilol; $\mathrm{r}=0.7325$, CI $95 \% 0.5580$ $0.8450, \mathrm{p}<0.0001$ for subgroup without carvedilol). The impact of statin administration could not be assessed because of low number of treated patients.
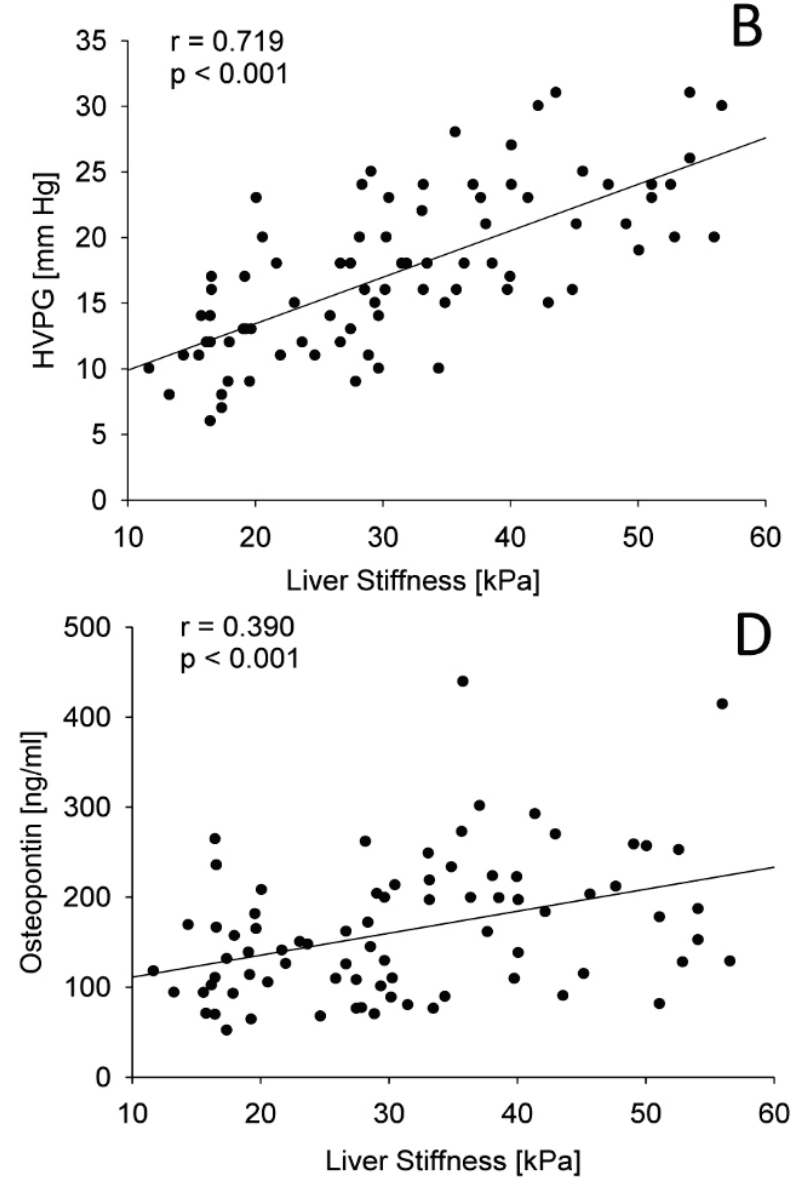

formation is:

$\mathrm{LS}=-0.41+(1,19 \times \mathrm{HVPG})+(0,26 \mathrm{x}$ CPA $)+(0.03 \times$ osteopontin),

or, after removal of osteopontin, impact of which on LS is low:

$\mathrm{LS}=2.48+(1.29 \times \mathrm{HVPG})+(0.26 \times \mathrm{CPA})$.

\section{Discussion}

The data obtained in our cohort of patients with advanced liver cirrhosis and $93 \%$ proportion of patients with CSPH strongly suggest that LS is determined predominantly by HVPG whereas contribution of liver collagen content to LS is less variable and relatively low. This conclusion is independently supported by four previously published studies with similar study design - 
Table 4. Multiple linear regression analysis.

\begin{tabular}{lc} 
Dependent variable & LS \\
Independent variables & p value \\
\hline HVPG [mm Hg] & $<\mathbf{0 . 0 0 0 1}$ \\
CPA [\%] & $\mathbf{0 . 0 0 6 9}$ \\
HP/Aminoacids [ng/nmol] & 0.7795 \\
ELF score [points] & 0.8659 \\
Hyaluronic acid [ng/ml] & 0.9113 \\
PIIINP [ng/ml] & 0.4730 \\
TIMP-1 [ng/ml] & 0.3691 \\
Osteopontin $(\mathrm{ng} / \mathrm{ml})$ & $\mathbf{0 . 0 2 7 8}$ \\
VCAM-1 [ng/ml] & 0.6735 \\
\hline
\end{tabular}

Table 5. Correlation of CPA with HVPG across the published studies.

\begin{tabular}{|c|c|c|c|c|c|}
\hline Publication & $\begin{array}{l}\text { Calvaruso } \\
\text { et al. } 2009\end{array}$ & $\begin{array}{c}\text { Isgro } \\
\text { et al. } 2013\end{array}$ & $\begin{array}{l}\text { Calvaruso } \\
\text { et al. } 2012\end{array}$ & $\begin{array}{l}\text { Nilesen } \\
\text { et al. } 2014\end{array}$ & Current study \\
\hline Patients population & HCV post LT & HCV post LT & HCV post LT & $\begin{array}{c}\text { Mixed } \\
\text { aetiology liver } \\
\text { cirrhosis }\end{array}$ & $\begin{array}{c}\text { Various } \\
\text { aetiology of } \\
\text { liver cirrhosis }\end{array}$ \\
\hline $\begin{array}{l}\text { Liver tissue specimen } \\
\text { aquisition }\end{array}$ & $\begin{array}{l}\text { Transjugular } \\
\text { biopsy }\end{array}$ & $\begin{array}{l}\text { Transjugular } \\
\text { biopsy }\end{array}$ & $\begin{array}{l}\text { Transjugular } \\
\text { biopsy }\end{array}$ & Explanted liver & Explanted liver \\
\hline Patients total, $N$ & $250 *$ & 63 & 62 & 41 & 81 \\
\hline $\begin{array}{l}\text { Patients with CSPH, } \\
N,(\%)\end{array}$ & $21(8 \%)$ & $7(18 \%)$ & $13(30 \%)$ & $31(76 \%)$ & $74(91 \%)$ \\
\hline $\begin{array}{l}C P A \text { vs. HVPG, } \\
\text { Spearman's } r,(p)\end{array}$ & $\begin{array}{c}0.61 \\
(\mathrm{p}<0.001)\end{array}$ & $\begin{array}{c}0.41 \\
(\mathrm{p}=0.01)\end{array}$ & $\begin{array}{c}0.37 \\
(\mathrm{p}=0.017)\end{array}$ & $\begin{array}{c}0.537 \\
(p<0.001)\end{array}$ & $\begin{array}{c}0.324 \\
(p=0.003)\end{array}$ \\
\hline
\end{tabular}

*250 measurements in 115 patients

HVPG measurement by hepatic vein catheterization and CPA assessment. Three of the studies were conducted on patients after liver transplantation for chronic $\mathrm{HCV}$ infection, the fourth study was done on liver transplant candidates with liver cirrhosis of various aetiologies. The proportions of non-cirrhotic and cirrhotic patients and the proportion of cirrhotic patients with and without CSPH were different across the studies. The highest proportion of patients with CSPH was in our cohort which included only cirrhotic patients. This allowed us to compare the relationship between CPA and HVPG across the studies (Table 5). Based on this comparison we realized that correlation between CPA and HVPG becomes weaker with increasing proportion of cirrhotic patients with CSPH in the study cohort.

It is also apparent that correlation between CPA and HVPG in patients after liver transplantation was generally weaker than in the non-transplanted subjects and decreased with the proportion of patients with $\mathrm{CSPH}$ in the cohort. The same trend was evident from the comparison of the data presented in (Nielsen et al. 2014) with our study.

Another two studies focused on correlation between CPA and LS; the correlation was weaker in the study with higher proportion of patients with cirrhosis. Buzzetti et al. (2019) evaluated 76 non-cirrhotic patients with NASH and the Spearman's r was 0.73 whereas in the non-transplanted HCV and HBV subgroups in the study by Calvaruso et al. (2012), the Spearman's r was 0.59 and 0.61 , respectively, and the proportion of patients with cirrhosis was 18 and $11 \%$, respectively. The Spearman's $r$ in our cohort of patients with liver cirrhosis was 0.441 . Our results thus comply with the concept explaining worsening of portal hypertension by intrahepatic 
angiogenesis in patients with advanced liver cirrhosis (Thabut and Shah 2010).

Our conclusion is further supported by the recent animal study indicating that formalin treated porcine liver showed increased stiffness and portal hypertension in the ex vivo model (Yang et al. 2017). Treatment of the liver with formalin modelled the changes in the liver collagen structure leading to the increase of portal pressure. Another animal study showed that in the perfused bovine liver start both: new collagen fibres production and tissue and vessels remodelling (Yarpuzlu et al. 2014).

In addition to CPA, we also assessed the HP/AA ratio as a collagen content marker in the explanted liver as an alternative assuming that HP/AA assessment might be superior for evaluation of liver collagen content. Accordingly, a recent MRI animal study showed good correlation of HP with the extracellular space in the liver (Luetkens et al. 2018). The HP/AA ratio showed the same correlation with HVPG as CPA and somewhat weaker correlation with LS. Contrarily, multiple linear regression identified only $\mathrm{CPA}$ to be the variable associated with LS. The fact that HP/AA correlated with the ELF score better than CPA is not surprising because ELF score is a composite parameter calculated from blood levels of three biomarkers associated with collagen turn-over. Based on these data, we speculate that CPA reflects not only liver collagen content but also collagen density and remodelling whereas the HP/AA is just an indicator of collagen content.

The design of our study allowed us to assess collagen content in substantially larger samples of the tissue than might have been obtained by transjugular liver biopsy performed together with HVPG measurement. On the other hand, this approach might have been associated with a methodological bias owing to the time period between LS and HVPG measurement and collagen content assessment in the explanted liver. However, in chronic liver diseases, the period between disease onset and advanced liver cirrhosis development takes years or decades whereas the interval between LS and HVPG measurement and LT took only a couple of weeks.

We conclude that our study brought new insight into pathophysiology and relevance of LS in patients with advanced liver cirrhosis. Correct interpretation of the LS value is important for understanding liver pathology and appropriate clinical decisions.

\section{Abbreviations}

CSPH, clinically significant portal hypertension; HA, hyaluronic acid; HVPG, Hepatic venous pressure gradient; LR, likelihood ratios; LS, Liver stiffness; LSPS, Liver Spleen Platelets Score; MELD, Model for End-Stage Liver Disease; NPV, negative predictive value, PH, Portal hypertension; PIIINP, Amino-Terminal Propeptide of Type III Procollagen; PPV, positive predictive value; TIMP-1, Tissue Inhibitor of Matrix Metalloproteinase 1; VCAM-1, Vascular Cell Adhesion Molecule 1; 2D-SWE, two-dimensional real time shearwave elastography.

\section{Conflict of Interest}

There is no conflict of interest.

\section{Acknowledgements}

The project was supported by Ministry of Health of the Czech Republic, grant No. 16-27546A. We express our gratitude to Lucie Budisova for her excellent technical assistance and Helena Pitelkova for the clinical coordination of the project.

\section{References}

ABRALDES JG, VILLANUEVA C, BANARES R, ARACIL C, CATALINA MV, GARCI APJC, BOSCH J, SPANISH COOPERATIVE GROUP FOR PORTAL H, VARICEAL B: Hepatic venous pressure gradient and prognosis in patients with acute variceal bleeding treated with pharmacologic and endoscopic therapy. J Hepatol 48: 229-36, 2008. https://doi.org/10.1016/j.jhep.2007.10.008

BERZIGOTTI A, BOSCH J: Pharmacologic management of portal hypertension. Clin Liver Dis 18: 303-17, 2014. https://doi.org/10.1016/j.cld.2013.12.003

BERZIGOTTI A, SEIJO S, ARENA U, ABRALDES JG, VIZZUTTI F, GARCIA-PAGAN JC, PINZANI M, BOSCH $\mathrm{J}$ : Elastography, spleen size, and platelet count identify portal hypertension in patients with compensated cirrhosis. Gastroenterology 144: 102-111 e1, 2013. https://doi.org/10.1053/j.gastro.2012.10.001

BOSCH J, ABRALDES JG, BERZIGOTTI A, GARCIA-PAGAN JC: The clinical use of HVPG measurements in chronic liver disease. Nat Rev Gastroenterol Hepatol 6: 573-582, 2009. https://doi.org/10.1038/nrgastro.2009.149 
BRUHA R, JACHYMOVA M, PETRTYL J, DVORAK K, LENICEK M, URBANEK P, SVESTKA T, VITEK L: Osteopontin: A non-invasive parameter of portal hypertension and prognostic marker of cirrhosis. World $\mathrm{J}$ Gastroenterol 22: 3441-50, 2016. https://doi.org/10.3748/wjg.v22.i12.3441

BUCK M, GARCIA-TSAO G, GROSZMANN RJ, STALLING C, GRACE ND, BURROUGHS AK, PATCH D, MATLOFF DS, CLOPTON P, CHOJKIER M: Novel inflammatory biomarkers of portal pressure in compensated cirrhosis patients. Hepatology 59: 1052-1059, 2014. https://doi.org/10.1002/hep.26755

BUZZETTI E, HALL A, EKSTEDT M, MANUGUERRA R, GUERRERO MISAS M, COVELLI C, LEANDRO G, LUONG T, KECHAGIAS S, MANESIS EK, PINZANI M, DHILLON AP, TSOCHATZIS EA: Collagen proportionate area is an independent predictor of long-term outcome in patients with non-alcoholic fatty liver disease. Aliment Pharmacol Ther 49: 1214-1222, 2019. https://doi.org/10.1111/apt.15219

CALVARUSO V, BURROUGHS AK, STANDISH R, MANOUSOU P, GRILLO F, LEANDRO G, MAIMONE S, PLEGUEZUELO M, XIROUCHAKIS I, GUERRINI GP, PATCH D, YU D, O'BEIRNE J, DHILLON AP: Computer-assisted image analysis of liver collagen: relationship to Ishak scoring and hepatic venous pressure gradient. Hepatology 49: 1236-1244, 2009. https://doi.org/10.1002/hep.22745

CALVARUSO V, DHILLON AP, TSOCHATZIS E, MANOUSOU P, GRILLO F, GERMANI G, PATCH D, O'BEIRNE J, BURROUGHS AK: Liver collagen proportionate area predicts decompensation in patients with recurrent hepatitis C virus cirrhosis after liver transplantation. J Gastroenterol Hepatol 27: 1227-1232, 2012. https://doi.org/10.1111/j.1440-1746.2012.07136.x

CASSINOTTO C, CHARRIE A, MOURIES A, LAPUYADE B, HIRIART JB, VERGNIOL J, GAYE D, HOCQUELET A, CHARBONNIER M, FOUCHER J, LAURENT F, CHERMAK F, MONTAUDON M, DE LEDINGHEN V: Liver and spleen elastography using supersonic shear imaging for the non-invasive diagnosis of cirrhosis severity and oesophageal varices. Dig Liver Dis 47: 695-701, 2015. https://doi.org/10.1016/j.dld.2015.04.008

CONEJO I, GUARDASCIONE MA, TANDON P, CACHERO A, CASTELLOTE J, ABRALDES JG, AMITRANO L, GENESCA J, AUGUSTIN S: Multicenter External Validation of Risk Stratification Criteria for Patients With Variceal Bleeding. Clin Gastroenterol Hepatol 16: 132-139 e8, 2018. https://doi.org/10.1016/j.cgh.2017.04.042

ELKRIEF L, RAUTOU PE, RONOT M, LAMBERT S, DIOGUARDI BURGIO M, FRANCOZ C, PLESSIER A, DURAND F, VALLA D, LEBREC D, VILGRAIN V, CASTERA L: Prospective comparison of spleen and liver stiffness by using shear-wave and transient elastography for detection of portal hypertension in cirrhosis. Radiology 275: 589-598, 2015. https://doi.org/10.1148/radiol.14141210

EUROPEAN ASSOCIATION FOR THE STUDY OF THE LIVER. ELECTRONIC ADDRESS EEE: EASL Clinical Practice Guidelines: Liver transplantation. J Hepatol 64: 433-485, 2016. https://doi.org/10.1016/j.jhep.2015.10.006

FRANKOVA S, LUNOVA M, GOTTFRIEDOVA H, SENKERIKOVA R, NEROLDOVA M, KOVAC J, KIESLICHOVA E, LANSKA V, URBANEK P, SPICAK J, JIRSA M, SPERL J: Liver stiffness measured by two-dimensional shear-wave elastography predicts hepatic vein pressure gradient at high values in liver transplant candidates with advanced liver cirrhosis. PLoS One 16: e0244934, 2021. https://doi.org/10.1371/journal.pone.0244934

FRIEDRICH-RUST M, ONG MF, MARTENS S, SARRAZIN C, BOJUNGA J, ZEUZEM S, HERRMANN E: Performance of transient elastography for the staging of liver fibrosis: a meta-analysis. Gastroenterology 134: 960-974, 2008. https://doi.org/10.1053/j.gastro.2008.01.034

GARCIA-TSAO G, GROSZMANN RJ, FISHER RL, CONN HO, ATTERBURY CE, GLICKMAN M: Portal pressure, presence of gastroesophageal varices and variceal bleeding. Hepatology 5: 419-424, 1985. https://doi.org/10.1002/hep.1840050313

GROSZMANN RJ, GARCIA-TSAO G, BOSCH J, GRACE ND, BURROUGHS AK, PLANAS R, ESCORSELL A, GARCIA-PAGAN JC, PATCH D, MATLOFF DS, GAO H, MAKUCH R, PORTAL HYPERTENSION COLLABORATIVE G: Beta-blockers to prevent gastroesophageal varices in patients with cirrhosis. N Engl J Med 353: 2254-2261, 2005. https://doi.org/10.1056/NEJMoa044456 
HOFFMAN DH, AYOOLA A, NICKEL D, HAN F, CHANDARANA H, BABB J, SHANBHOGUE KP: MR elastography, T1 and T2 relaxometry of liver: role in noninvasive assessment of liver function and portal hypertension. Abdom Radiol (NY) 45: 2680-2687, 2020. https://doi.org/10.1007/s00261-020-02432-7

ISGRO G, CALVARUSO V, ANDREANA L, LUONG TV, GARCOVICH M, MANOUSOU P, ALIBRANDI A, MAIMONE S, MARELLI L, DAVIES N, PATCH D, DHILLON AP, BURROUGHS AK: The relationship between transient elastography and histological collagen proportionate area for assessing fibrosis in chronic viral hepatitis. J Gastroenterol 48: 921-929, 2013. https://doi.org/10.1007/s00535-012-0694-9

KAMATH PS, KIM WR, ADVANCED LIVER DISEASE STUDY G: The model for end-stage liver disease (MELD). Hepatology 45: 797-805, 2007. https://doi.org/10.1002/hep.21563

KENNEDY P, WAGNER M, CASTERA L, HONG CW, JOHNSON CL, SIRLIN CB, TAOULI B: Quantitative elastography methods in liver disease: current evidence and future directions. Radiology 286: 738-763, 2018. https://doi.org/10.1148/radiol.2018170601

LEBREC D, DE FLEURY P, RUEFF B, NAHUM H, BENHAMOU JP: Portal hypertension, size of esophageal varices, and risk of gastrointestinal bleeding in alcoholic cirrhosis. Gastroenterology 79: 1139-1144, 1980. https://doi.org/10.1016/0016-5085(80)90905-1

LI Y, HUANG YS, WANG ZZ, YANG ZR, SUN F, ZHAN SY, LIU XE, ZHUANG H: Systematic review with metaanalysis: the diagnostic accuracy of transient elastography for the staging of liver fibrosis in patients with chronic hepatitis B. Aliment Pharmacol Ther 43: 458-469, 2016. https://doi.org/10.1111/apt.13488

LUETKENS JA, KLEIN S, TRABER F, SCHMEEL FC, SPRINKART AM, KUETTING DLR, BLOCK W, USCHNER FE, SCHIERWAGEN R, HITTATIYA K, KRISTIANSEN G, GIESEKE J, SCHILD HH, TREBICKA J, KUKUK GM: Quantification of liver fibrosis at T1 and T2 mapping with extracellular volume fraction MRI: Preclinical results. Radiology 288: 748-754, 2018. https://doi.org/10.1148/radiol.2018180051

LUNOVA M, GOEHRING C, KUSCUOGLU D, MUELLER K, CHEN Y, WALTHER P, DESCHEMIN JC, VAULONT S, HAYBAECK J, LACKNER C, TRAUTWEIN C, STRNAD P: Hepcidin knockout mice fed with iron-rich diet develop chronic liver injury and liver fibrosis due to lysosomal iron overload. J Hepatol 61: 633-641, 2014. https://doi.org/10.1016/j.jhep.2014.04.034

MAZZAFERRO V, REGALIA E, DOCI R, ANDREOLA S, PULVIRENTI A, BOZZETTI F, MONTALTO F, AMMATUNA M, MORABITO A, GENNARI L: Liver transplantation for the treatment of small hepatocellular carcinomas in patients with cirrhosis. N Engl J Med 334: 693-699, 1996. https://doi.org/10.1056/NEJM199603143341104

MCCONNELL M, IWAKIRI Y: Biology of portal hypertension. Hepatol Int 12: 11-23, 2018. https://doi.org/10.1007/s12072-017-9826-X

MIELE L, De MiCHELE T, MARRONE G, ANTONIETTA ISGRO M, BASILE U, CEFALO C, BIOLATO M, MARIA VECCHIO F, LODOVICO RAPACCINI G, GASBARRINI A, ZUPPI C, GRIECO A: Enhanced liver fibrosis test as a reliable tool for assessing fibrosis in nonalcoholic fatty liver disease in a clinical setting. Int J Biol Markers 32: e397-e402, 2017. https://doi.org/10.5301/ijbm.5000292

MORISHITA N, HIRAMATSU N, OZE T, HARADA N, YAMADA R, MIYAZAKI M, YAKUSHIJIN T, MIYAGI T, YOSHIDA Y, TATSUMI T, KANTO T, TAKEHARA T: Liver stiffness measurement by acoustic radiation force impulse is useful in predicting the presence of esophageal varices or high-risk esophageal varices among patients with HCV-related cirrhosis. J Gastroenterol 49: 1175-1182, 2014. https://doi.org/10.1007/s00535-013$\underline{0877-z}$

NIELSEN K, CLEMMESEN JO, VASSILIADIS E, VAINER B: Liver collagen in cirrhosis correlates with portal hypertension and liver dysfunction. APMIS 122: 1213-1222, 2014. https://doi.org/10.1111/apm.12287

PARKES J, GUHA IN, RODERICK P, HARRIS S, CROSS R, MANOS MM, IRVING W, ZAITOUN A, WHEATLEY M, RYDER S, ROSENBERG W: Enhanced Liver Fibrosis (ELF) test accurately identifies liver fibrosis in patients with chronic hepatitis C. J Viral Hepat 18: 23-31, 2011. https://doi.org/10.1111/j.13652893.2009.01263.X 
PARKES J, RODERICK P, HARRIS S, DAY C, MUTIMER D, COLLIER J, LOMBARD M, ALEXANDER G, RAMAGE J, DUSHEIKO G, WHEATLEY M, GOUGH C, BURT A, ROSENBERG W: Enhanced liver fibrosis test can predict clinical outcomes in patients with chronic liver disease. Gut 59: 1245-1251, 2010. https://doi.org/10.1136/gut.2009.203166

PROCOPET B, BERZIGOTTI A, ABRALDES JG, TURON F, HERNANDEZ-GEA V, GARCIA-PAGAN JC, BOSCH J: Real-time shear-wave elastography: applicability, reliability and accuracy for clinically significant portal hypertension. J Hepatol 62: 1068-1075, 2015. https://doi.org/10.1016/j.jhep.2014.12.007

RIPOLL C, GROSZMANN R, GARCIA-TSAO G, GRACE N, BURROUGHS A, PLANAS R, ESCORSELL A, GARCIA-PAGAN JC, MAKUCH R, PATCH D, MATLOFF DS, BOSCH J, PORTAL HYPERTENSION COLLABORATIVE G: Hepatic venous pressure gradient predicts clinical decompensation in patients with compensated cirrhosis. Gastroenterology 133: 481-488, 2007. https://doi.org/10.1053/j.gastro.2007.05.024

SANDRIN L, FOURQUET B, HASQUENOPH JM, YON S, FOURNIER C, MAL F, CHRISTIDIS C, ZIOL M, POULET B, KAZEMI F, BEAUGRAND M, PALAU R: Transient elastography: a new noninvasive method for assessment of hepatic fibrosis. Ultrasound Med Biol 29: 1705-1713, 2003. https://doi.org/10.1016/j.ultrasmedbio.2003.07.001

SHAHEEN AA, WAN AF, MYERS RP: FibroTest and FibroScan for the prediction of hepatitis C-related fibrosis: a systematic review of diagnostic test accuracy. Am J Gastroenterol 102: 2589-600, 2007. https://doi.org/10.1111/j.1572-0241.2007.01466.X

SHI KQ, FAN YC, PAN ZZ, LIN XF, LIU WY, CHEN YP, ZHENG MH: Transient elastography: a meta-analysis of diagnostic accuracy in evaluation of portal hypertension in chronic liver disease. Liver Int 33: 62-71, 2013. https://doi.org/10.1111/liv.12003

SILVA-JUNIOR G, BAIGES A, TURON F, TORRES F, HERNANDEZ-GEA V, BOSCH J, GARCIA-PAGAN JC: The prognostic value of hepatic venous pressure gradient in patients with cirrhosis is highly dependent on the accuracy of the technique. Hepatology 62: 1584-1592, 2015. https://doi.org/10.1002/hep.28031

SIMBRUNNER B, MARCULESCU R, SCHEINER B, SCHWABL P, BUCSICS T, STADLMANN A, BAUER DJM, PATERNOSTRO R, EIGENBAUER E, PINTER M, STATTERMAYER AF, TRAUNER M, MANDORFER M, REIBERGER T: Non-invasive detection of portal hypertension by enhanced liver fibrosis score in patients with different aetiologies of advanced chronic liver disease. Liver Int 40: 1713-1724, 2020. https://doi.org/10.1111/liv.14498

SINGH S, VENKATESH SK, LOOMBA R, WANG Z, SIRLIN C, CHEN J, YIN M, MILLER FH, LOW RN, HASSANEIN T, GODFREY EM, ASBACH P, MURAD MH, LOMAS DJ, TALWALKAR JA, EHMAN RL: Magnetic resonance elastography for staging liver fibrosis in non-alcoholic fatty liver disease: a diagnostic accuracy systematic review and individual participant data pooled analysis. Eur Radiol 26: 1431-1440, 2016. https://doi.org/10.1007/s00330-015-3949-z

SINGH S, VENKATESH SK, WANG Z, MILLER FH, MOTOSUGI U, LOW RN, HASSANEIN T, ASBACH P, GODFREY EM, YIN M, CHEN J, KEAVENY AP, BRIDGES M, BOHTE A, MURAD MH, LOMAS DJ, TALWALKAR JA, EHMAN RL: Diagnostic performance of magnetic resonance elastography in staging liver fibrosis: a systematic review and meta-analysis of individual participant data. Clin Gastroenterol Hepatol 13: 440-451 e6, 2015. https://doi.org/10.1016/j.cgh.2014.09.046

STEBBING J, FAROUK L, PANOS G, ANDERSON M, JIAO LR, MANDALIA S, BOWER M, GAZZARD B, NELSON M: A meta-analysis of transient elastography for the detection of hepatic fibrosis. J Clin Gastroenterol 44: 214-219, 2010. https://doi.org/10.1097/MCG.0b013e3181b4aflf

STEFANESCU H, RUSU C, LUPSOR-PLATON M, NICOARA FARCAU O, FISCHER P, GRIGORAS C, HORHAT A, STANCU O, ARDELEAN A, TANTAU M, BADEA R, PROCOPET B: Liver stiffness assessed by ultrasound shear wave elastography from general electric accurately predicts clinically significant portal hypertension in patients with advanced chronic liver disease. Ultraschall Med 2019. https://doi.org/10.1055/a$\underline{0965-0745}$

TALWALKAR JA, KURTZ DM, SCHOENLEBER SJ, WEST CP, MONTORI VM: Ultrasound-based transient elastography for the detection of hepatic fibrosis: systematic review and meta-analysis. Clin Gastroenterol Hepatol 5: 1214-1220, 2007. https://doi.org/10.1016/j.cgh.2007.07.020 
THABUT D, SHAH V: Intrahepatic angiogenesis and sinusoidal remodeling in chronic liver disease: new targets for the treatment of portal hypertension? J Hepatol 53: 976-980, 2010. https://doi.org/10.1016/j.jhep.2010.07.004

THIELE M, HUGGER MB, KIM Y, RAUTOU PE, ELKRIEF L, JANSEN C, VERLINDEN W, ALLEGRETTI G, ISRAELSEN M, STEFANESCU H, PISCAGLIA F, GARCIA-PAGAN JC, FRANQUE S, BERZIGOTTI A, CASTERA L, JEONG WK, TREBICKA J, KRAG A: 2D shear wave liver elastography by Aixplorer to detect portal hypertension in cirrhosis: An individual patient data meta-analysis. Liver Int 40: 1435-1446, 2020. https://doi.org/10.1111/liv.14439

TSOCHATZIS EA, GURUSAMY KS, NTAOULA S, CHOLONGITAS E, DAVIDSON BR, BURROUGHS AK: Elastography for the diagnosis of severity of fibrosis in chronic liver disease: a meta-analysis of diagnostic accuracy. J Hepatol 54: 650-659, 2011. https://doi.org/10.1016/j.jhep.2010.07.033

WIESNER R, EDWARDS E, FREEMAN R, HARPER A, KIM R, KAMATH P, KREMERS W, LAKE J, HOWARD T, MERION RM, WOLFE RA, KROM R, UNITED NETWORK FOR ORGAN SHARING LIVER DISEASE SEVERITY SCORE C: Model for end-stage liver disease (MELD) and allocation of donor livers. Gastroenterology 124: 91-96, 2003. https://doi.org/10.1053/gast.2003.50016

WIESNER RH, MCDIARMID SV, KAMATH PS, EDWARDS EB, MALINCHOC M, KREMERS WK, KROM RA, KIM WR: MELD and PELD: application of survival models to liver allocation. Liver Transpl 7: 567-580, 2001. https://doi.org/10.1053/jlts.2001.25879

YANG C, YIN M, GLASER KJ, ZHU X, XU K, EHMAN RL, CHEN J: Static and dynamic liver stiffness: An ex vivo porcine liver study using MR elastography. Magn Reson Imaging 44: 92-95, 2017. https://doi.org/10.1016/j.mri.2017.08.009

YARPUZLU B, AYYILDIZ M, TOK OE, AKTAS RG, BASDOGAN C: Correlation between the mechanical and histological properties of liver tissue. J Mech Behav Biomed Mater 29: 403-416, 2014. https://doi.org/10.1016/j.jmbbm.2013.09.016

YIN M, KOLIPAKA A, WOODRUM DA, GLASER KJ, ROMANO AJ, MANDUCA A, TALWALKAR JA, ARAOZ PA, MCGEE KP, ANAVEKAR NS, EHMAN RL: Hepatic and splenic stiffness augmentation assessed with MR elastography in an in vivo porcine portal hypertension model. J Magn Reson Imaging 38: 809-815, 2013. https://doi.org/10.1002/jmri.24049

YOU MW, KIM KW, PYO J, HUH J, KIM HJ, LEE SJ, PARK SH: A Meta-analysis for the diagnostic performance of transient elastography for clinically significant portal hypertension. Ultrasound Med Biol 43: 59-68, 2017. https://doi.org/10.1016/j.ultrasmedbio.2016.07.025 